\title{
Article
}

\section{Do entrepreneurs always benefit from business failure experience?}

Boso, Nathaniel, Adeleye, Ifedapo, Donbesuur, Francis and Gyensare, Michael

Available at http://clok.uclan.ac.uk/28485/

Boso, Nathaniel, Adeleye, Ifedapo, Donbesuur, Francis ORCID: 0000-00033793-802X and Gyensare, Michael (2019) Do entrepreneurs always benefit from business failure experience? Journal of Business Research, 98 . pp. 370379. ISSN 0148-2963

It is advisable to refer to the publisher's version if you intend to cite from the work. http://dx.doi.org/10.1016/j.jbusres.2018.01.063

For more information about UCLan's research in this area go to http://www.uclan.ac.uk/researchgroups/ and search for <name of research Group>.

For information about Research generally at UCLan please go to http://www.uclan.ac.uk/research/

All outputs in CLoK are protected by Intellectual Property Rights law, including Copyright law. Copyright, IPR and Moral Rights for the works on this site are retained by the individual authors and/or other copyright owners. Terms and conditions for use of this material are defined in the policies page.

\section{CLoK}

Central Lancashire online Knowledge www.clok.uclan.ac.uk

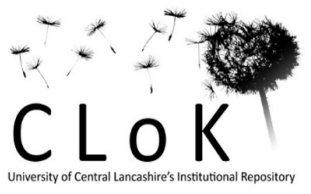




\title{
Do entrepreneurs always benefit from business failure experience?
}

\author{
Francis Donbesuur \\ Nathaniel Boso \\ Ifedapo Adeleye \\ Michael Gyensare
}

\begin{abstract}
Business failure and its effect on entrepreneurial engagement has attracted substantial scholarly attention in entrepreneurship research. We contend that knowledge is lacking on the entrepreneurial learning mechanism and entrepreneurial alertness condition under which business failure experience influences new venture performance. In an empirical examination of 240 entrepreneurs operating in multiple industries in a sub-Saharan African country, we use a longitudinal data set to show that business failure experience does not always influence new venture performance. Rather, business failure experience influences new venture performance when it is channelled through entrepreneurial learning under conditions of increasing levels of entrepreneurial learning and a greater degree of alertness to new business opportunities. We discuss these findings and provide avenues for extending this emerging area of scholarly research.
\end{abstract}

Key words: business failure experience; learning from failure; entrepreneurial alertness; new venture performance; sub-Saharan Africa 


\section{Introduction}

Business failure experience and its consequences have attracted substantial scholarly attention (e.g., Ucbasaran, Westhead, Wright, and Flores, 2010; Cope, 2011). A contention is that the aftermath of business failure entails a feeling of loss and a process of recovery for entrepreneurs (Amankwah-Amoah, Boso, and Antwi-Agyei, 2016; Jenkins, Wiklund, and Brundin, 2014). Research suggests that business failure experience generates financial, social and psychological losses to entrepreneurs (Ucbasaran, Shepherd, Lockett, and Lyon, 2013). Despite the losses, scholars have argued that the loss phase is often followed by a period of sense-making and learning from the failure, and subsequently an entrepreneurial reemergence (Shepherd and Cardon, 2009; Ucbasaran et al., 2013). Thus, it is argued that an ability to learn from failure may be a process through which entrepreneurs re-engage in new entrepreneurial actions (Cope, 2011; Shepherd and Cardon, 2009; Shepherd, Patzelt, and Wolfe, 2011).

Although the business failure literature has acknowledged learning from failure as an important entrepreneurial process (Ucbasaran et al., 2013; Yamakawa, Peng, and Deeds, 2015), knowledge is lacking on how learning from failure connects business failure experience to new venture performance. Additionally, while previous research has examined how an entrepreneur's cognitive capability influences new venture performance (e.g., Tang, Kacmar, and Busenitz, 2012), scholarly knowledge is limited on how entrepreneur's alertness to new business opportunities complements or substitutes for the entrepreneur's ability to learn to boost new venture performance. It is important to address this gap in the scholarly literature because although small business start-ups account for nearly $70 \%$ of employment globally and $90 \%$ in the developing world (Page and Söderbom, 2015), the failure rate among start-ups currently stands at an alarming rate of approximately 90\% (Patel, 2015), indicating an urgent need to better understand the performance consequences of business failure among 
entrepreneurs. In this study, we examine whether and under what conditions business failure experience influences subsequent entrepreneurial actions.

Furthermore, prior research on business failure and its consequences is skewed towards business enterprises in the developed markets of Western Europe and North America. However, the scope of business failure is expanding dramatically, raising concerns about the adequacy of existing contextualization on business failure research. For example, sub-Saharan Africa is noted for chronic business environment turbulence that provides a breeding ground for new start-ups to fail (Owusu and Habiyakare, 2011). Interestingly, scholarly research on business failure experience among African entrepreneurs remains limited. Thus, it is important that research on business failure is broadened to capture evidence from more 'exotic' contexts, such as sub-Saharan Africa (Eggers and Song, 2015; Amankwah-Amoah et al., 2016).

The study makes three important contributions to the business failure literature. First, while several studies have proposed learning as a potential mechanism through which failure experience might drive entrepreneurs to reengage in entrepreneurial activity (e.g., Shepherd et al., 2011; Cope, 2011), theoretical specification and empirical analysis of this relationship is incomplete. This study fills this gap by integrating insights from experiential learning and resource-based theories to examine how learning from failure connects business failure experience to new venture performance. Specifically, we draw on experiential learning theory to argue that failure experience provides entrepreneurs with an opportunity to learn to move forward to subsequently exploit an entrepreneurial opportunity (Ucbasaran et al., 2013). By drawing on the resource-based theory, we conceptualize failure experience as a resource that feed into the entrepreneurs' ability to transform the knowledge acquired through failure experience into a new entrepreneurial action. 
Second, the entrepreneurship research suggests that alertness to new business opportunities provides entrepreneurs with an ability to recognize and exploit new business ideas to recover from losses from prior failure (Tang et al., 2012). However, it remains unclear whether entrepreneurial alertness can facilitate or depress the effect of learning from failure on new venture performance. Hence, this study further draws on the resource-based theory to identify entrepreneurial alertness as a cognitive capability that may condition the effect of failure experience influences on new venture performance through learning from failure. We define entrepreneurial alertness as the ability of an entrepreneur to identify a new business opportunity that has previously been overlooked by others (Kirzner, 1973).

Third, the business failure research has long been dominated by empirical evidence from developed and industrialized markets. However, market conditions in developing societies are noted to be highly turbulent and evolving with serious implications for the survival and growth of new ventures in those societies (Bruton, Ahlstrom, and Obloj, 2008; Yamakawa, Peng, and Deeds, 2015). Therefore, in contributing to the contextual understanding of business failure and its consequences, this study focuses on the empirical analysis of the consequences of prior business failure experience of entrepreneurs operating in an African economy, thus bringing into fore a unique empirical setting for understanding the business failure phenomenon.

\section{Theoretical background and hypotheses}

\subsection{Business failure experience and its outcomes}

Business failure has been defined in the literature in diverse ways (e.g., Shepherd and Haynie, 2011; Ucbasaran et al., 2010); Ucbasaran et al. (2013) define business failure as the cessation of involvement in a venture because it has not met a minimum threshold for economic viability as specified by the entrepreneur. The aftermath of a business failure is 
argued to constitute a process that entails the business failure event, business failure cost, sense-making and learning processes and re-emergence (Ucbasaran et al., 2013). An argument is that in the aftermath of a business failure experience, entrepreneurs take stock of the immediate costs of the failure, which may include financial, social, and psychological losses (Cope, 2011; Eggers and Song, 2015). In building on these earlier studies, AmankwahAmoah et al. (2016) uncover the following four distinctive phases of post entrepreneurial business failure: the grief and despair, transition, formation, and legacy phases. They conclude that business failure experience has the potential to influence an entrepreneur's subsequent entrepreneurial actions.

In examining the behavioural consequences of business failure experience, Ucbasaran et al. (2013) argue that a process of re-emergence occurs, whereby the entrepreneur makes efforts to recover from the failure. While recovery from failure may entail several interrelated phases (see Cope, 2011; Amankwah-Amoah et al., 2016), research shows that the final stage of recovery from failure is associated with entrepreneurs making an effort to start and grow a new venture (Cope, 2011). For example, entrepreneurs with business failure experience (i.e., closure of at least one venture) are noted to have a greater propensity to exploit a new business opportunity in a given period than their counterparts with no failure experience (Ucbasaran, Alsos, Westhead and Wright, 2008). Yamakawa and Cardon (2015) examine entrepreneurs who started business for the second time after an initial failure and find that failure experience drives subsequent venture creation. Other scholars have reported a strong relationship between failure experience and new venture start-up activities (e.g., Mitchell, Mitchell, and Smith 2008; Politis and Gabrielsson, 2009).

However, it has been argued that business failure experience might not always impact subsequent new venture creation. For example, Ucbasaran, Westhead and Wright (2009), in a study of 630 entrepreneurs in the United Kingdom, find that there is an inverse U-shaped 
relationship between failed business experience and the number of new businesses subsequently started. Additionally, evidence suggests that failure experience has no relationship with subsequent new business start-up (e.g., Yamakawa and Cardon, 2015). Thus, the empirical evidence relating business failure experience to new venture performance remains inconclusive.

Given the inconclusiveness of the empirical evidence on the outcomes of business failure experience, scholars have called for additional empirical research to further establish how and when business failure experience impacts the subsequent entrepreneurial actions (including new venture creation). For example, Ucbasaran et al (2009) suggest that future studies should examine how learning from failure experience serves as a conduit to connecting failure experience to a subsequent new venture start-up. This reasoning is highlighted in Eggers and Song (2015), where it is argued that an ability to harness learning from failure experience becomes a key underlying mechanism through which failure experience causes entrepreneurs to start new businesses subsequently. The learning consequences of failure experience are further highlighted in the work of Cope (2011), who argue that in the aftermath of failure, there is a period of sense-making and learning, whereby entrepreneurs with failed ventures step back to consider the key drivers of the failure, while making sense of the process to facilitate new learning. Along this line, the business failure literature suggests that business failure provides entrepreneurs with a rich experience and information from which learning originates to drive future new venture formation (Eggers and Song, 2015).

In summary, although business failure experience may engender learning and a subsequent new business start-up, evidence is lacking on this relationship. In particular, theoretical specification of the underlying mechanism through which learning connects failure experience to new venture performance remains under-studied. In addressing this 
major gap in the business failure literature, this study draws on the resource based theory to conceptualize business failure experience as an entrepreneurial resource that affords entrepreneurs experiential knowledge to launch and grow a new venture. The study proposes that learning from failure serves as a channel through which business failure experience impacts on new venture performance, conditional upon the degree of entrepreneurial alertness (see Figure 1).

Figure 1

\subsection{The role of learning}

Although prior research has speculated about the processes that connect business failure experience to the entrepreneurs' ability to start and grow new ventures (e.g., Ucbasaran et al., 2013), articulation of how learning from failure intervenes on the effect of failure experience on new venture performance remains under-developed. This study fills this gap in the extant business failure literature by accounting for the mediating role of learning. Learning from failure is defined as the cognitive capability of entrepreneurs to develop new knowledge by drawing on prior failure experiences to identify and exploit new opportunities (Corbett, 2007). This definition is in line with Man's (2006) theoretical framework, which views learning as a capability that is dynamic and evolving. From a resource-based perspective, we view learning from failure as a capability that determines the entrepreneurs' ability to integrate, build, and reconfigure multiple sources of knowledge to identify and exploit opportunities in the market environment (Teece, 2012; Teece, Pisano, and Shuen 1997). Learning as a capability, therefore, determines the speed at, and degree to which, an entrepreneur aligns and realigns experiences from prior business failures to exploit new business opportunities. 
Along this line, Cope (2011) argues that recovery and re-emergence from failure is a function of a distinctive learning process that fosters a range of higher-level learning capabilities. Thus, entrepreneurs learn not only about the demise of their venture but also about how they can draw on lessons learnt to start and grow a new venture. Cope (2011) posits that learning is future-oriented and triggers an entrepreneur's level of preparedness for further enterprising activities. In drawing insights from these prior studies, Hajizadeh and Zali (2016) find that the entrepreneurs' ability to learn from their prior business experiences drives the entrepreneurs' ability to start and grow successful new ventures. Accordingly, this study advances the previous business failure research by arguing that learning from failure is a competence that connects business failure experience to new venture performance. Hence, we propose the following:

H1: Business failure experience is positively related to new venture performance.

H2: Entrepreneurial learning mediates the effect of business failure experience on new venture performance.

\subsection{Moderating role of entrepreneurial alertness}

This study argues that the extent to which business failure experience influences subsequent new venture creation via the processes of learning may be dependent upon the entrepreneurs' ability to identify and exploit new entrepreneurial opportunities. Alertness to new opportunities is a conditioning force in that such an ability enables the entrepreneur recovering from a failure to more quickly convert the knowledge gained from the failure into a new venture creation. Entrepreneurial alertness relates to an entrepreneur's ability to identify and exploit an opportunity that has otherwise been overlooked by others (Kirzner, 1973). Building from Kirzner's (1973) cognition theory, and McMullen and Shepherd's (2006) later development of the alertness construct, Tang et al. (2012) developed a model 
comprising the following three elements of entrepreneurial alertness: scanning and search, association and connection, and evaluation and judgement. As a cognitive ability and information processing capability, alertness provides entrepreneurs with an ability to acquire (scan and search for information), organize (associate and connect information) and interpret (evaluate and judge) information from different perspectives to exploit new opportunities (Gaglio and Katz, 2001; Tang et al., 2012). Against this background, this study contends that entrepreneurs who are alert to new opportunities are more likely to be knowledgeable about, and sensitive to, changes in the environment; hence, they have a greater likelihood of exploiting opportunities to create and grow new business ventures. This follows the logic that the higher the level of alertness, the higher the possibility that individuals will develop a positive attitude towards exploiting new entrepreneurial opportunities. Along this this line, Hou (2008) finds the individuals with strong entrepreneurial alertness are more capable of launching new ventures.

It is our contention that entrepreneurs with experiential knowledge of failure and greater alertness to new opportunities are more likely to be successful in starting and growing new ventures. This contention is predicated on the notion that entrepreneurial alertness provides the previously failed entrepreneur with a conscious search behavioural tendency to look for new business opportunities and an increased knowledge of failure and success factors in the environment, which may consequently lead the entrepreneur to undertake a more accurate evaluation of the new opportunities identified (Hajizadeh and Zali, 2016). With an increased alertness to searching, connecting and evaluating new opportunities, entrepreneurs with failure experience are able to convert their knowledge of failure into determining new opportunities worth pursuing (McMullen and Shepherd, 2006).

While empirical studies on the joint effect of learning from failure and alertness is limited, this study argues that learning from failure and alertness to new opportunities are 
potentially complementary capabilities that, when high in magnitude, can drive new venture performance. We argue that because learning from a failure experience enables an entrepreneur to incorporate personal experiences to develop an entrepreneurial knowledge base, the new venture performance outcome of this knowledge base is likely to be boosted when it is complemented with an entrepreneur's cognitive ability to process information on available new business opportunities. Thus, with a greater ability to learn from failure and with a stronger propensity to search, connect and evaluate information on new business opportunities, an entrepreneur is more likely to launch and grow a new business venture. Accordingly, we propose the following hypothesis:

H3. The effect of business failure experience on new venture performance via entrepreneurial learning capability is strengthened when entrepreneurial alertness increases in magnitude.

\subsection{Methods}

\subsubsection{Study setting}

As argued earlier, much of the successes and failures of entrepreneurial entities have been extensively studied in industrialized economies of Western Europe, North America and North-East Asia. However, we have in recent years witnessed rapid economic shifts to the extent that business enterprises in developing economy markets are now leading in many industries globally, such that Western multinationals now find themselves competing not only with business enterprises from other industrialized nations but also against smaller businesses from emerging markets (Bruton, Ketchen, and Ireland, 2013). Although developed country multinational enterprises have traditionally monopolized economic activities in African economies, the recent emergence of activities of African privately owned business enterprises as major players in the region has introduced new competitive dynamics and promises to shape the future of these economies (Kaplinsky and Morris, 2009). Interestingly, although 
much academic and public policy attention has so far been directed at understanding how African business enterprises can be assisted to grow, the present study looks at the evolving landscape from a new angle. We focus on examining how African entrepreneurs can leverage their experiences with business failure to launch and grow new business ventures.

\subsubsection{Sample and data collection procedure}

We followed precedence (e.g., Villena, Revilla, and Choi, 2011) to adopt a longitudinal research design using data from entrepreneurs in Nigeria, the largest emerging economy in sub-Saharan Africa. In line with our research objectives, we focus on the business failure experience of the entrepreneurs, and examine its effect on the entrepreneurs' ability to start and grow new ventures. In view of the diversity of different failure experiences that entrepreneurs may have been involved in, and the potential length of time that entrepreneurs might take to learn from the such experiences, the current research follows prior entrepreneurship research practice (e.g., Wiklund and Shepherd, 2011) to focus on the entrepreneurs' experiences during the 2013 to 2015 period (Muthusamy and White, 2005). The three-year time frame helped ensure that we studied new venture success outcomes several years after the business failure experience had occurred. We focused on entrepreneurs that have operated in multiple industries, i.e., fast moving consumer goods (FMCG), hospitality (e.g., hotels, restaurants and attractions), pharmaceutical, machinery and automobile industries, because formal entrepreneurial activity occurs frequently in these industries in sub-Saharan Africa. Hence, our unit of analysis is the individual entrepreneur's actions. The list of the entrepreneurs studied was developed from the Nigerian industrial association and a directory of SMEs in Nigeria. Eventually, a sampling frame of 886 entrepreneurs was created. After a series of telephone calls, emails and face-to-face contacts, 539 entrepreneurs agreed to participate in the study. 
In September 2013, all 539 entrepreneurs in the sampling frame were contacted in person and provided with a survey instrument, together with a letter endorsing the study by the public relations and marketing directorate of a major business school in Nigeria. The entrepreneurs were instructed to provide information on their previous three years of business failure experiences. To enhance participation, each entrepreneur was promised an executive summary of the study and a one-day workshop on entrepreneurial capability development. Eventually, 256 valid responses were received, representing a $47.95 \%$ response rate. In September 2014, all 256 entrepreneurs were contacted once again in person with a separate set of surveys to assess the extent to which the entrepreneurs had learnt lessons from their business failure experience and the extent to which they have been alert to new entrepreneurial opportunities. A total of 240 valid responses were received, representing a response rate of $93.75 \%$. Then, in September 2015, we returned to the 240 entrepreneurs for information on the performance of the new ventures they had started. All 240 entrepreneurs provided complete information on their new venture performance measures, something that was attributed to the good rapport that the study's interviewers developed with the entrepreneurs in the 2013 and 2014 studies. Emails were subsequently sent to the entrepreneurs in September 2016 to gain additional information on the new venture performance indicators. Thus, for the purposes of establishing causality, we pooled the 2015 and the 2016 new venture performance data to capture our dependent variables, the 2014 data to generate the intermediate and the moderator variables and the 2013 data to create our independent variable. In that way, we analysed our proposed relationships with time lags between the dependent, the intermediate/moderator and independent variables based on multiple-time frame data.

The entrepreneurs studied operate in the following industries: FMCGs (26\%); automobile parts (25\%); hospitality (11\%); pharmaceutical (11\%); financial services (10\%); 
industrial machinery (10\%) and; agro-processing (7\%). The average age of the entrepreneurs is 45 years; and the average entrepreneurial experience is 22 years. A majority of the entrepreneurs have a university education (72\%), while the remaining $28 \%$ have secondary and vocational education.

\subsubsection{Measure development}

Before we commenced the survey data collection, a series of qualitative interviews were undertaken to develop and refine the measures used to operationalize the study's constructs. The interviews also helped to generate contextual information on the entrepreneurial activity in Nigeria and other African markets. Specifically, in 2012, one of the authors assembled six entrepreneurs for a three-hour focus group discussion on their entrepreneurial and business failure experiences. Following insights generated from the focus group discussion, interviews were conducted with 18 entrepreneurs across three African countries (10 in Nigeria, 5 in Ghana and 3 in Kenya). Some of the interviews were conducted once, others twice and some thrice to clarify certain comments made by the entrepreneurs. The entrepreneurs interviewed had a variety of experiences operating in Africa: while some entrepreneurs had operated for 20 years on average, others had been doing business for an average of 10 years. The entrepreneurs cited a variety of reasons why they chose entrepreneurship as a career path; for example, "I have a strong desire to be autonomous"; "I want to control my destiny"; "I have spotted an opportunity that others cannot see"; and "I want to be rich". Key entrepreneurial success factors cited included the capability to understand market knowledge and culture, and a willingness to learn from mistakes. Another reason was a propensity to solve local market problems and to deliver products and services on time and to the expectation of local consumers. All entrepreneurs affirmed that their ability to spot opportunities in home and neighbouring African markets was a key driver of 
their new venture success. Others contended that their willingness to partner with likeminded entrepreneurs and leverage their social networks was a major determinant of their success; for example, one entrepreneur stated that, "I was lucky to know this guy in Abidjan [the commercial capital of Ivory Coast] who linked me to a local chief in his village, which helped me obtain preferential access to land and labour for our production plant".

We then followed Ozcan and Eisenhardt (2009) to develop context-sensitive measures by asking the entrepreneurs questions about their business failure experiences, learning activities, their alertness to new opportunities and new business start-ups. While the interviews were tape recorded, to document and immediately verify the interviewees' comments, the interviewers also took extensive notes during the interviews. In accordance with acceptable qualitative data analysis practices (e.g., Ozcan and Eisenhardt, 2009), the interview data was transcribed, and coded by one author in line with the resource-capabilityperformance framework (Lu, Zhou, Bruton, and Li, 2010). A recommended practice in qualitative research is to enhance coding reliability (Ozcan and Eisenhardt, 2009). Accordingly, a professional research firm with extensive experience in conducting qualitative research in Nigeria was hired to check and recode the interviews using a structured coding template. A strong inter-coder agreement of .88 was obtained between the two coders.

We find several themes emerging from the interview data that translated into the notion of interplay between business failure experiences, learning from failure, alertness to new business opportunity and new business performance. The entrepreneurs mostly emphasized that their experiences with business failure (despite the losses that immediately followed) were an important ingredient in their learning activities. One entrepreneur of a pharmaceutical business venture commented that, "I learnt lots of lessons from the previous failure because that failure taught me that I needed to develop skills in understanding and sensing trends on the market and establish useful contacts with key supply chain networks". 
Together, the development of our measures was aided by a combination of information from the interviews, documentary reviews of business failure and learning experiences of the entrepreneurs, and review of the existing academic literature on business failure and entrepreneurial learning and capability. After integrating the information from these multiple sources, a structured questionnaire was designed in the English language. All the questionnaire administrators had substantial experience conducting fieldwork in sub-Saharan Africa, helping to ensure that the study captured reliable data from the firms on the key constructs.

\subsubsection{Business failure experience}

We relied on data from the interviews and the extant literature to capture the business failure experience construct. Specifically, in line with the existing literature, a business failure was assumed "to have taken place if the respondent had closed or sold a business due to bankruptcy, liquidation or receivership, or if the business had been closed or sold because it had failed to meet the expectations of the entrepreneur" (Ucbasaran et al., 2010, p. 6). Insights from the interviews enabled us to exclude novice entrepreneurs from our study, because this group of entrepreneurs (with one or two businesses) may not have experienced business failure. Hence, entrepreneurs with a minimum of one previous business failure experience were asked to complete the questionnaire. Accordingly, we captured business failure experience by asking each entrepreneur to report on "the total number of failed businesses they had owned" (Ucbasaran et al., 2010, p. 6).

\subsubsection{Learning from failure}

The learning construct was based on Yamakawa and Cardon's (2015) perceived learning from entrepreneurial failure, Homsma, Van Dyck, De Gilder, Koopman, and 
Elfring's (2009) learning from error and DeClercq and Sapienza's (2005) venture capital firm learning scales. The scales are used to capture the degree of perceived new insights or broader understandings an entrepreneur gains from failure experience. This scale was administered one year after the business failure experiences had occurred; the items were measured on 7-point scale, with $1=$ learnt nothing at all from the experience, and $7=$ learnt extremely from the experience. The items demonstrate strong internal consistency (see Table 1).

\subsubsection{Entrepreneurial alertness}

Entrepreneurial alertness was operationalized to comprise the following three dimensions: ability to scan and search for new information; a capability to connect different information; and an ability to evaluate whether information reveals an entrepreneurial opportunity. The three dimensions were measured on a 13-item scale borrowed from Tang et al. (2012) and measured on a 7-point scale, with $1=$ strongly disagree and $7=$ strongly agree. Sample items included "I am always actively looking for new information" (capturing scanning and search); "I see links between seemingly unrelated pieces of information" (tapping association and connection); and "I have an extraordinary ability to smell profitable opportunities" (measuring evaluation and judgement). As Table 1 shows, the scales show acceptable internal consistency.

\subsubsection{New venture performance}

New venture success was operationalized as the extent to which a new venture meets an entrepreneur's financial performance goals. The actual measures capturing the new venture success construct were adapted from previous studies (e.g., Luk et al., 2008). The entrepreneurs were asked to evaluate the extent to which their new venture's performance 
indicators (i.e., unit sales, unit sales growth, market share and market share growth) met the entrepreneurs' performance goals for the venture. The scale was captured on a 7-point scale with the following anchors: $1=$ very much worse than expected and $7=$ very much better than expected. The items showed excellent internal consistency (Table 1).

\subsubsection{Controls}

Following the existing business failure literature (e.g., Eggers and Song, 2015; Yamakawa and Cardon, 2015), we controlled for industry, firm, and individual entrepreneur related effects, as logic and previous research suggests that these variables may influence new venture success (Tang et al. (2012). Specifically, we controlled for the potential confounding effects of perceived market turbulence, industry type (manufacturing $=0$; services $=1$ ), venture size (number of staff employed by the venture), venture age (number of years in operation), entrepreneur business experience (number of new ventures started), social network ties (Shane and Cable, 2002), business network ties (Luo, 2003), local community ties (Acquaah, 2012), gender of the entrepreneur $(0=$ male; $1=$ female $)$, entrepreneurs' education (formal education $=0$; no formal education $=1$ ), and number of partners at the start of the new business.

\section{Analyses}

\subsection{Tests of reliability and validity}

We followed the procedure recommended by Bagozzi and Yi (2012) to conduct confirmatory factor analysis (CFA) for all constructs that were measured with multiple indicators. We used the maximum likelihood estimation method, implemented in LISREL 8.71 for the analyses. The exact model fit was evaluated using the conventional chi-square 
( $\chi 2)$ difference tests. Following the suggestion of Hu and Bentler (1999) and Bagozzi and Yi (2012), we also assessed a combination of approximate fit heuristics to provide a broader evaluation of model fit. Specifically, Bagozzi andYi (2012) recommend that non-centrality based measures, such as root mean square error of approximation (RMSEA); relative fit indices, including non-normed fit index (NNFI) and comparative fit index (CFI) and; the absolute fit index, such as standardized root mean squared residual (SRMR) of model fit should be reported. The psychometric literature suggests that the normed chi-square (i.e., $\chi^{2} /$ d.f.) should be ideally less than $2.00, \mathrm{RMSEA} \leq .07, \mathrm{NNFI} \geq .90, \mathrm{CFI} \geq$ and $\mathrm{SRMR} \leq$ .07(Bagozzi and Yi, 2012). Based on these criteria, we obtained excellent fit to the data: $\chi^{2} /$ d.f. $=801.43 / 398=2.01 ; \mathrm{NNFI}=.93 ; \mathrm{CFI}=.95 ; \mathrm{RMSEA}=.06 ;$ and $\mathrm{SRMR}=.05 . \mathrm{A}$ normed chi-square of 2.01 is within the recommended acceptable range (e.g., Bagozzi and Yi, 2012).

Next, we subjected all constructs to reliability, convergent validity and discriminant validity tests. The standardized factor loadings for each item are significant at $1 \%$, providing support for convergent validity (see Table 1). As can also be seen in Table 1, the composite reliability $(\mathrm{CR})$ values for each construct exceed the required benchmarks of .60, confirming the reliability of the constructs (Fornell and Larcker, 1981). Using Fornell and Larcker's (1981) test, we assessed the discriminant validity of measures to determine whether the average variance extracted (AVE) for each construct exceeded the highest shared variance (HSV) of each pair of constructs. In comparing the AVE values in Table 1 and the interconstruct correlations in Table 2, we demonstrate discriminant validity because the AVE for each construct is larger than the HSV between each pair of constructs.

Table 1 and Table 2 here 


\subsection{Common method bias assessment}

We followed procedural and statistical methods to respectively minimize and test for common method bias (Podsakoff, MacKenzie, Lee, and Podsakoff, 2003). Although we allowed a time lag between the independent and dependent variables, our data still came from a single source. To this end, it could be argued that our study design may suffer from common method bias. To address this concern, we took additional steps to determine whether common method bias was present in the data. Specifically, we estimated three competing common method bias CFA models. In Model 1, we estimated a method-only model, in which all indicators were loaded on a single latent factor but obtained a poor fit to the data as follows: $\chi 2 / \mathrm{DF}=8221.17 / 434 ; \mathrm{RMSEA}=.27 ; \mathrm{NNFI}=.17 ; \mathrm{CFI}=.22 ; \mathrm{SRMR}=.24 . \mathrm{In}$ Model 2, we evaluated a trait-only model in which each indicator was loaded on its respective latent factor, and a good fit was obtained, as follows: $\chi^{2} /$ d.f. $=801.43 / 398 ; \mathrm{NNFI}=.93 ; \mathrm{CFI}=$ $.95 ;$ RMSEA $=.06$; and SRMR =.05. In model 3, we examined a method-and-trait-model involving inclusion of a common factor linking all the indicators in model 2 and obtained an acceptable model fit as follows: $\chi 2 / \mathrm{DF}=791.48 / 358 ; \mathrm{RMSEA}=.06 ; \mathrm{NNFI}=.91 ; \mathrm{CFI}=.93$; $\mathrm{SRMR}=.05$. Subsequently, we compared the three models to determine which one fit the data best. The findings indicate that model 2 and model 3 are superior to model 1 and that model 3 is not substantially better than model 2 , suggesting that common method bias does not sufficiently describe our data.

\subsection{Structural model estimation}

Having established the validity of our multi-item constructs, we created single indicants to reduce model complexity. Specifically, we calculated averages for learning from failure (LF) and entrepreneurial alertness (EA). To help achieve a sufficient degree of freedom, we modelled new venture performance with its four specified indicators. The 
single-item scores were subsequently used in the path analysis for the purposes of testing for the study's hypotheses. Because product-term analysis was performed to test the hypotheses, a multiplicative term was created, and this was then used to estimate our structural paths. Specifically, a multiplicative term was created for LF x EA to estimate hypotheses 3 . There was a potential for the multicollinearity problem arising from the introduction of the multiplicative term; hence the two variables involved in the multiplicative interaction were orthogonalized (Little, Boviard and Widaman, 2006). Consequently, Equation 1 and Equation 2 were produced and simultaneously estimated in LISREL 8.5 using the maximum likelihood estimation method.

\section{Equation 1:}

Learning from Failure $=[\mathrm{A}+\mathrm{B}+\mathrm{C}+\mathrm{D}+\mathrm{E}+\mathrm{F}+\mathrm{G}+\mathrm{H}+\mathrm{I}+\mathrm{J}+\mathrm{K}+[\mathrm{FE}]+\varepsilon 1$

\section{Equation 2:}

New venture performance $=[\mathrm{A}+\mathrm{B}+\mathrm{C}+\mathrm{D}+\mathrm{E}+\mathrm{F}+\mathrm{G}+\mathrm{H}+\mathrm{I}+\mathrm{J}+\mathrm{K}+[\mathrm{FE}]+[\mathrm{EA}+\mathrm{LF}]$ $+[$ LFxEA $]+\varepsilon 1$

Where: $\mathrm{A}=$ venture size; $\mathrm{B}=$ venture age; $\mathrm{C}=$ number of ventures started $; \mathrm{D}=$ number of venture partners; $\mathrm{E}=$ gender; $\mathrm{F}=$ social networking; $\mathrm{G}=$ business networking; $\mathrm{H}=$ local community networking; $\mathrm{I}=$ education; $\mathrm{J}=$ industry; $\mathrm{K}=$ market turbulence; $\mathrm{FE}=$ failure experience; EA entrepreneurial alertness; $L F=$ learning from failure; and $\varepsilon 1=$ error term.

Subsequently, we estimated six hierarchical nested models. Model 1 and Model 2 have learning as an outcome variable. Model 1 contained only the control variables, while the independent variable (i.e., failure experience) was added in Model 2. Model 3 to Model 6 have new venture performance as the outcome variable. In Model 3, we estimated the control variables, while in Model 4, we estimated the direct effect of failure experience on new 
venture performance. The direct effects of learning and alertness were added in Model 5. In Model 6, the interaction effect variable (i.e., LF x EA) was added to the equation. An additional analysis was undertaken in Model 7 to explore potential quadratic effects of learning. Hence, in Model 7, a quadratic-interaction variable (LF-Squared x EA) was added (see Equation 3).

\section{Equation 3:}

New venture performance $=[\mathrm{A}+\mathrm{B}+\mathrm{C}+\mathrm{D}+\mathrm{E}+\mathrm{F}+\mathrm{G}+\mathrm{H}+\mathrm{I}+\mathrm{J}+\mathrm{K}+[\mathrm{FE}]+[\mathrm{EA}+\mathrm{LF}]$

$+[\mathrm{LFxEA}]+\left[\mathrm{LF}^{2}\right]+\left[\mathrm{LF}^{2} \mathrm{xEA}\right]+\varepsilon 1$

where: $\mathrm{EL}^{2}=\mathrm{LF}$ squared.

In estimating these multiple models, we were able to note changes in R-square $\left(\mathrm{R}^{2}\right)$ and $\chi^{2} /$ degrees of freedom and stability of our parameter estimates as new variables were added to the models. The standardized coefficients and the significance levels for the seven models are presented in Table 3.

Table 3 here

\section{Findings}

The study argues in hypothesis 1 that business failure experience is positively related to new venture performance. The findings from the study (see Table 3) indicate support for hypothesis 1 as follows: the failure experience $\rightarrow$ new venture performance relationship is significant in Model $4(\gamma=.22 ; \mathrm{t}=2.56 ; \mathrm{p}<0.05)$. However, hypothesis 1 is only a baseline path estimated in the study. The study then argues in hypothesis 2 that learning from failure mediates the effect of business failure experience on new venture performance, which is a competing hypothesis to hypothesis 1 . As Model 5 in Table 3 shows, the failure experience 
$\rightarrow$ new venture performance relationship becomes nonsignificant $(\gamma=.10 ; t=1.12 ; p>0.10)$, while the failure experience $\rightarrow$ learning relationship $(\gamma=.15 ; \mathrm{t}=2.03 ; \mathrm{p}<0.05)$, and the learning $\rightarrow$ new venture performance relationships are significant $(\gamma=.18 ; t=2.68 ; \mathrm{p}<0.01)$. Accordingly, we reject hypothesis 1 in favour of hypothesis 2. In fact, in Model 6 and Model 7, when the path from failure experience to new venture performance is channelled through learning, the effect of failure experience on new venture performance continues to drop dramatically, providing support for hypothesis 2 . The study contends in hypothesis 3 that the effect of business failure experience on new venture performance via learning is strengthened when alertness increases in magnitude, a competing hypothesis to hypothesis 1 and hypothesis 2. As we show in Model 6, the indirect effect of failure experience on new venture performance via learning remains unchanged at varying levels of alertness $(\gamma=.07 ; \mathrm{t}=1.13$; p> 0.10); hence, hypothesis 3 is rejected in favour of hypothesis 2 .

To explore hypothesis 3 further, we evaluated the moderating effect structural paths at \pm 1 standard deviation from the mediator (learning) and the moderator (alertness) variables. Specifically, we squared the mean-centred learning (i.e., LF squared) variable and multiplied it with a mean-centred alertness (EA) variable, enabling us to assess the moderating effect relationship at lower (-1 SD below the mean) and higher (+1 SD above the mean) levels of learning. As we show in Model 7 in Table 3 and Figure 1, the findings show that the LF squared $\mathrm{x}$ EA interaction term is positive and significantly related to new venture performance $(\gamma=.27 ; \mathrm{t}=2.60 ; \mathrm{p}<0.01)$. This finding suggests that the extent to which learning impacts new venture performance is dependent upon increasing levels of learning and higher levels of alertness to new entrepreneurial opportunities, essentially providing support for hypothesis 3 .

Figure 2 here 


\section{Discussion, implications and directions for future research}

This research examines the following major question in the business failure literature: how and when does business failure experience drive new venture performance? To investigate this question empirically, this study examined the number of business failure experiences of entrepreneurs and modelled its effect on new venture performance. The study then explored how this relationship is channelled through learning from failure and is conditional upon levels of entrepreneurial alertness. The findings from an empirical study in an African economy show that business failure experience has a positive effect on new venture performance. In addition, the findings show that the positive effect of business failure experience on new venture performance becomes insignificant when failure experience is channelled through learning from failure. Furthermore, the indirect effect of failure experience via learning from failure on new venture performance becomes stronger when levels of alertness to new business opportunities are greater. Overall, these findings from the study provide a number of theoretical contributions to the business failure literature.

First, prior research on business failure speculates that an experience with business failure gives entrepreneurs an experiential resource that can be leveraged in subsequent attempts to create and grow a new venture (e.g., Shepherd and Cardon, 2009). While this proposition may be appealing, recent scholarly works suggest that experience with business failure might not necessarily drive new venture performance. To support this argument, Yamakawa et al. (2015) study entrepreneurs who had started business for the second time in Japan and find that no relationship exists between prior business failure experience and new venture growth. Similarly, in a study of entrepreneurs in Great Britain, Ucbasaran et al. (2009) find that an inverse U-shaped relationship between the proportion of failed businesses and the number of new businesses owned by entrepreneurs. In line with these few prior 
empirical studies, this study finds that business failure experience does not have a direct effect on new venture performance. Unlike previous studies, this study finds that the effect of business failure experience on new venture performance is channelled through the entrepreneurs' ability to learn from experiencing failure. This new finding provides empirical backing to the growing contention in the business failure literature that new venture success is determined by the entrepreneurs' ability to learn from their failure experience (Politis and Gabrielsson, 2009; Ucbasaran et al., 2009). This study, therefore, enriches the business failure literature by showing that the mechanism through which business failure experience drives new venture performance is the entrepreneurs' ability to learn from their business failures.

Second, this study proposes that the degree of alertness to entrepreneurial opportunities - a cognitive capability - may facilitate the extent to which failure experience influences new venture performance through learning. Findings from this study show that the effect of learning from failure experience on new venture performance is strengthened when learning increases above its average level and when alertness to new opportunities has higher values (see Figure 2). A theoretical implication is that learning is a dynamic phenomenon, with its new venture performance effect driven by the extent to which entrepreneurs continue to increase learning competences through constant review of lessons drawn from prior failure experiences. This finding highlights Yamakawa et al.'s (2015) argument that the entrepreneurs' ability to re-emerge from failure to engage in subsequent entrepreneurial activity is dependent upon their cognitive ability to identify and exploit new business opportunities. Thus, findings suggest that the benefits from an increasing level of learning from failure are facilitated when entrepreneurs continue to search, evaluate and act upon new business opportunities. 
In addition to the theoretical contributions, this study offers two important entrepreneurial management and policy making lessons. First, the findings from the study suggests that over and above the losses that often immediately follow from failure, business failure experience enables entrepreneurs to develop learning capabilities that subsequently drive the success of new ventures subsequently created. An implication for entrepreneurs is that failure should not be viewed as the end of the entrepreneurial journey; rather, it should be viewed as a learning opportunity and a chance to venture into new entrepreneurial actions. In terms of policy making, the findings from the study suggest that efforts should be expended to instil in sub-Saharan African societies a culture that accepts failure as part of entrepreneurial journey if such societies are utilize entrepreneurship as a driver of growth. Second, while learning from previous business failure may help entrepreneurs succeed in their new business ventures, the efficacy of this experiential learning to drive new venture performance is boosted by the entrepreneurs' cognitive ability to be alert to new business opportunities. A key lesson for entrepreneurs is that continuous learning and a greater propensity to search for new information for renewal and growth of new ventures is a major success factor. For policy makers, support for entrepreneurs with a recent experience with failure in the form of financial, educational and psychological counselling services may be a viable means to sustain resilience among entrepreneurs in the society.

The findings reported in this study are limited in a number of ways, providing a path for future research. First, although the context of this study is unique, this is still a single country study, and therefore, conclusions can only be limited to the Nigerian entrepreneurs studied. One way to extend this study further is to increase the number of countries and cultural settings to help broaden our perspectives on business failure and its consequences. We believe that perspectives on business failure may vary as a result of cultural and institutional differences. For example, could the effect of business failure experience on 
subsequent new venture creation be dependent upon national cultural and/or institutional differences? Additional research is needed to fully address this question.

Second, this study acknowledges that a feeling of loss (e.g., financial, social and/or psychological loss) immediately follows an experience with business failure before learning occurs. This potential for a mediating effect of loss on the relationship between failure experience and learning is not tested in this study. Hence, an argument can be made that entrepreneurs with greater feelings of loss are less likely to learn from the failure as opposed to entrepreneurs who exhibit a smaller degree of loss (Shepherd, 2003). To this end, an important avenue for future research is to examine the extent to which the dual recovery process of loss orientation and restoration orientation helps explain the effect business failure experience has on learning from failure.

Third, it has been argued that entrepreneurs who have failed in a previous venture tend to blame the external environment (e.g., industry) for the failure rather than themselves (Eggers and Song, 2015). However, scholars have argued that internal failure attributions are associated with greater perceived learning, while external failure attributions are associated with less perceived learning (Yamakawa and Cardon, 2015). We suggest that future research should explore whether the type of failure attribution moderates the relationship between business failure experience and learning.

\section{Conclusion}

This study proposes and finds empirical support for the contention that learning from business failure serves as a channel through which business failure experience influences new venture performance depending upon increasing levels of learning and greater levels of alertness to new entrepreneurial opportunities. Given that this study has theoretically discussed and empirically tested the causal mechanism linking business failure experience to 
new venture performance in the sub-Saharan African context, we have opened the door for stronger theoretical grounding of the business failure research, especially in less researched societies. 


\section{References}

Acquaah, M. (2012). Social networking relationships, firm- specific managerial experience and firm performance in a transition economy: a comparative analysis of family owned and nonfamily firms. Strategic Management Journal, 33, 1215-1228. doi:10.1002/smj.1973.

Amankwah-Amoah, J., Boso, N., \& Antwi-Agyei, I. (2016). The effects of business failure experience on successive entrepreneurial engagements. Group and Organization Management, 1-35. doi:10.1177/1059601116643447.

Bagozzi, R. P., \& Yi, Y. (2012). Specification, evaluation, and interpretation of structural equation models. Journal of the Academy of Marketing Science, 40, 8-34. doi:10.1007/s11747-011-0278-x.

Bruton, G. D., Ahlstrom, D., \& Obloj, K. (2008). Entrepreneurship in emerging economies: where are we today and where should the research go in the future. Entrepreneurship Theory and Practice, 32, 1-14. doi:10.1111/j.1540-6520.2007.00213.x.

Bruton, G. D., Ketchen, D. J., \& Ireland, R. D. (2013). Entrepreneurship as a solution to poverty. Journal of Business Venturing, 28, 683-689.

doi:10.1016/j.jbusvent.2013.05.002.

Cope, J. (2011). Entrepreneurial learning from failure: an interpretative phenomenological analysis. Journal of Business Venturing, 26, 604-623. doi:10.1016/j.jbusvent.2010.06.002.

Corbett, A. C. (2007). Learning asymmetries and the discovery of entrepreneurial opportunities. Journal of Business Venturing, 22, 97-118.

doi:10.1016/j.jbusvent.2005.10.001. 
DeClercq, D. D., \& Sapienza, H. J. (2005). When do venture capital firms learn from their portfolio Companies? Entrepreneurship Theory and Practice, 29, 517-535. doi:10.1111/j.1540-6520.2005.00096.x.

Eggers, J. P., \& Song, L. (2015). Dealing with failure: serial entrepreneurs and the costs of changing industries between ventures. Academy of Management Journal, 58, 17851803. doi:10.5465/amj.2014.0050.

Fornell, C., \& Larcker, D. F. (1981). Structural equation models with unobservable variables and measurement error: algebra and statistics. Journal of Marketing Research, 18, 382388. doi:10.2307/3150980.

Gaglio, C. M., \& Katz, J. A. (2001). The psychological basis of opportunity identification: entrepreneurial alertness. Small Business Economics, 16, 95-111. doi:10.1023/A:1011132102464.

Hajizadeh, A., \& Zali, M. (2016). Prior knowledge, cognitive characteristics and opportunity recognition. International Journal of Entrepreneurial Behavior \& Research, 22, 63-83. doi:10.1108/IJEBR-05-2015-0110.

Homsma, G. J., Van Dyck, C., De Gilder, D., Koopman, P. L., \& Elfring, T. (2009). Learning from error: the influence of error incident characteristics. Journal of Business Research, 62, 115-122. doi:10.1016/j.jbusres.2007.12.003.

Hou, S. T. (2008). Antecedents and consequence of entrepreneurial alertness in franchise chain. $4^{\text {th }}$ IEEE International Conference on Management of Innovation and Technology. 2008, 166-171.

Hu, L. T., \& Bentler, P. M. (1999). Cutoff criteria for fit indexes in covariance structure analysis: conventional criteria versus new alternatives. Structural Equation Modeling: a Multidisciplinary Journal, 6, 1-55. doi:10.1080/10705519909540118. 
Jenkins, A. S., Wiklund, J., \& Brundin, E. (2014). Individual responses to firm failure: appraisals, grief, and the influence of prior failure experience. Journal of Business Venturing, 29, 17-33. doi:10.1016/j.jbusvent.2012.10.006.

Kaplinsky, R., \& Morris, M. (2009). Chinese FDI in Sub-Saharan Africa: engaging with large dragons. European Journal of Development Research, 21, 551-569. doi:10.1057/ejdr.2009.24.

Kirzner, I. M. (1973). Competition and entrepreneurship. Chicago: University of Chicago Press.

Little, T. D., Bovaird, J. A., \& Widaman, K. F. (2006). On the merits of orthogonalizing powered and product terms: implications for modeling interactions among latent variables. Structural Equation Modeling: A Multidisciplinary Journal, 13, 497-519. doi:10.1207/s15328007sem1304_1.

Lu, Y., Zhou, L., Bruton, G., \& Li, W. (2010). Capabilities as a mediator linking resources and the international performance of entrepreneurial firms in an emerging economy. Journal of International Business Studies, 41, 419-436. doi:10.1057/jibs.2009.73.

Luk, C. L., Yau, O. H. M., Sin, L. Y. M., Tse, A. C. B., Chow, R. P. M., \& Lee, J. S. Y. (2008). The effects of social capital and organizational innovativeness in different institutional contexts. Journal of International Business Studies, 39, 589-612. doi:10.1057/palgrave.jibs.8400373.

Luo, Y. (2003). Industrial dynamics and managerial networking in an emerging market: the case of China. Strategic Management Journal, 24, 1315-1327. doi:10.1002/smj.363.

Man, T. W. Y., \& T. (2006). Exploring the behavioural patterns of entrepreneurial learning. Education + Training, 48, 309-321. doi:10.1108/00400910610677027. 
McMullen, J. S., \& Shepherd, D. A. (2006). Entrepreneurial action and the role of uncertainty in the theory of the entrepreneur. Academy of Management Review, 31, 132-152. doi:10.5465/AMR.2006.19379628.

Mitchell, R. K., Mitchell, J. R., \& Smith, J. B. (2008). Inside opportunity formation: enterprise failure, cognition, and the creation of opportunities. Strategic Entrepreneurship Journal, 2, 225-242. doi:10.1002/sej.51.

Muthusamy, S. K., \& White, M. A. (2005). Learning and knowledge transfer in strategic alliances: a social exchange view. Organization Studies, 26, 415-441. doi:10.1177/0170840605050874.

Owusu, R. A., \& Habiyakare, E. (2011). Managing risk and turbulence in internationalization of foreign companies to South Africa: lessons from seven Finnish business-to-business firms. Journal of African Business, 12, 218-237. doi:10.1080/15228916.2011.588913.

Ozcan, P., \& Eisenhardt, K. M. (2009). Origin of alliance portfolios: entrepreneurs, network strategies, and firm performance. Academy of Management Journal, 52, 246-279. doi:10.5465/AMJ.2009.37308021.

Page, J., \& Söderbom, M. (2015). Is small beautiful? Small enterprise, aid and employment in Africa. African Development Review, 27, 44-55. doi:10.1111/1467-8268.12138.

Patel, N. (2015). 90\% of startups fail: here's what you need to know about the $10 \%$. Forbes. Community.

Podsakoff, P. M., MacKenzie, S. B., Lee, J. Y., \& Podsakoff, N. P. (2003). Common method biases in behavioral research: a critical review of the literature and recommended remedies. Journal of Applied Psychology, 88, 879-903. doi:10.1037/00219010.88.5.879. 
Politis, D., \& Gabrielsson, J. (2009). Entrepreneurs' attitudes towards failure. International Journal of Entrepreneurial Behavior \& Research, 15, 364-383. doi:10.1108/13552550910967921.

Shane, S., \& Cable, D. (2002). Network ties, reputation, and the financing of new ventures. Management Science, 48, 364-381. doi:10.1287/mnsc.48.3.364.7731.

Shepherd, D. A. (2003). Learning from business failure: propositions of grief recovery for the self-employed. Academy of Management Review, 28, 318-328. doi:10.5465/AMR.2003.9416377.

Shepherd, D. A., \& Cardon, M. S. (2009). Negative emotional reactions to project failure and the self- compassion to learn from the experience. Journal of Management Studies, 46, 923-949. doi:10.1111/j.1467-6486.2009.00821.x.

Shepherd, D. A., \& Haynie, J. M. (2011). Venture failure, stigma, and impression management: A self- verification, self- determination view. Strategic Entrepreneurship Journal, 5, 178-197. doi:10.1002/sej.113.

Shepherd, D. A., Patzelt, H., \& Wolfe, M. (2011). Moving forward from project failure: negative emotions, affective commitment, and learning from the experience. Academy of Management Journal, 54, 1229-1259. doi:10.5465/amj.2010.0102.

Tang, J., Kacmar, K. M. (, \& Busenitz, L. (2012). Entrepreneurial alertness in the pursuit of new opportunities. Journal of Business Venturing, 27, 77-94. doi:10.1016/j.jbusvent.2010.07.001.

Teece, D. J. (2012). Dynamic capabilities: routines versus entrepreneurial action. Journal of Management Studies, 49, 1395-1401. doi:10.1111/j.1467-6486.2012.01080.x.

Teece, D. J., Pisano, G., \& Shuen, A. (1997). Dynamic capabilities and strategic management. Strategic Management Journal, 18, 509-533. doi:10.1002/(SICI)10970266(199708)18:7<509::AID-SMJ882>3.0.CO;2-Z. 
Ucbasaran, D., Alsos, G. A., Westhead, P., \& Wright, M. (2007). Habitual entrepreneurs. Foundations and Trends ${ }^{\circledR}$ in Entrepreneurship, 4, 309-450. doi:10.1561/0300000014.

Ucbasaran, D., Shepherd, D. A., Lockett, A., \& Lyon, S. J. (2013). Life after business failure. Journal of Management, 39, 163-202. doi:10.1177/0149206312457823.

Ucbasaran, D., Westhead, P., \& Wright, M. (2009). The extent and nature of opportunity identification by experienced entrepreneurs. Journal of Business Venturing, 24, 99-115. doi:10.1016/j.jbusvent.2008.01.008.

Ucbasaran, D., Westhead, P., Wright, M., \& Flores, M. (2010). The nature of entrepreneurial experience, business failure and comparative optimism. Journal of Business Venturing, 25, 541-555. doi:10.1016/j.jbusvent.2009.04.001.

Villena, V. H., Revilla, E., \& Choi, T. Y. (2011). The dark side of buyer-supplier relationships: A social capital perspective. Journal of Operations Management, 29, 561-576. doi:10.1016/j.jom.2010.09.001.

Wiklund, J., \& Shepherd, D. A. (2011). Where to from here? EO- as- experimentation, failure, and distribution of outcomes. Entrepreneurship Theory and Practice, 35, 925946. doi:10.1111/j.1540-6520.2011.00454.x.

Yamakawa, Y., \& Cardon, M. S. (2015). Causal ascriptions and perceived learning from entrepreneurial failure. Small Business Economics, 44, 797-820. doi:10.1007/s11187014-9623-z.

Yamakawa, Y., Peng, M. W., \& Deeds, D. L. (2015). Rising from the ashes: cognitive determinants of venture growth after entrepreneurial failure. Entrepreneurship Theory and Practice, 39, 209-236. doi:10.1111/etap.12047. 
Figure 1: Theoretical Framework

H1: +

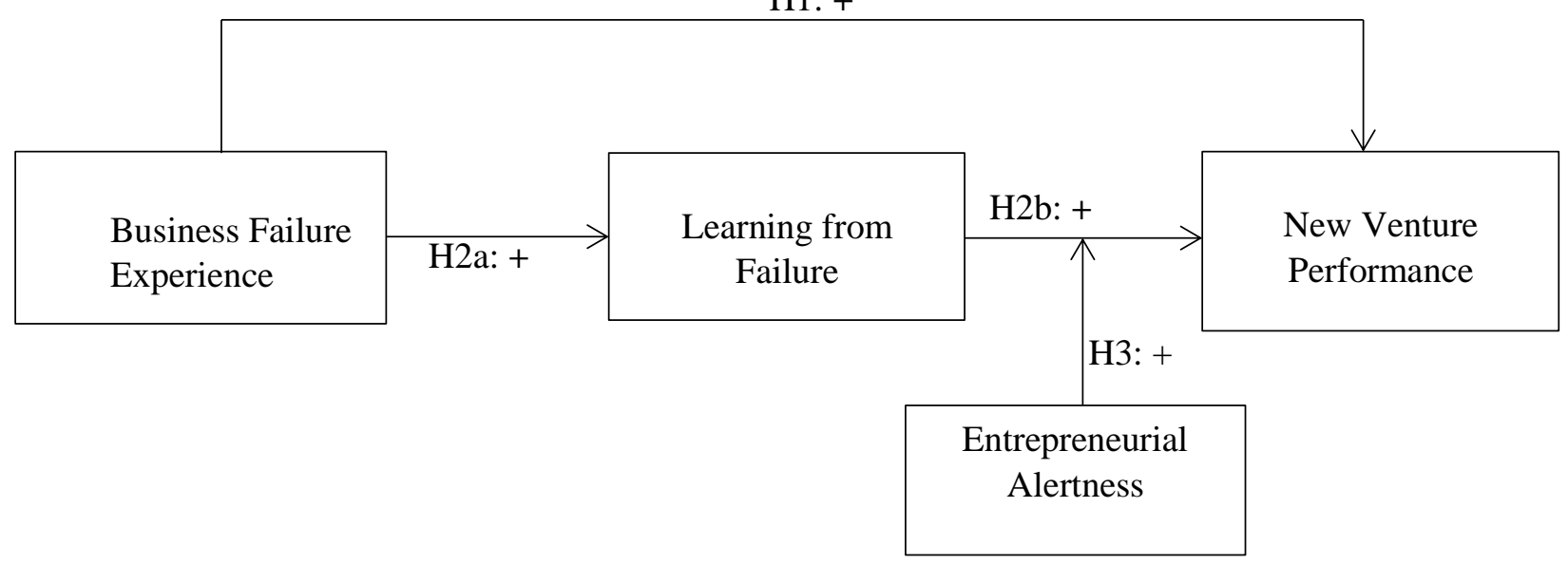


Figure 2: Surface Plot of the Moderating Effect of Entrepreneurial Alertness

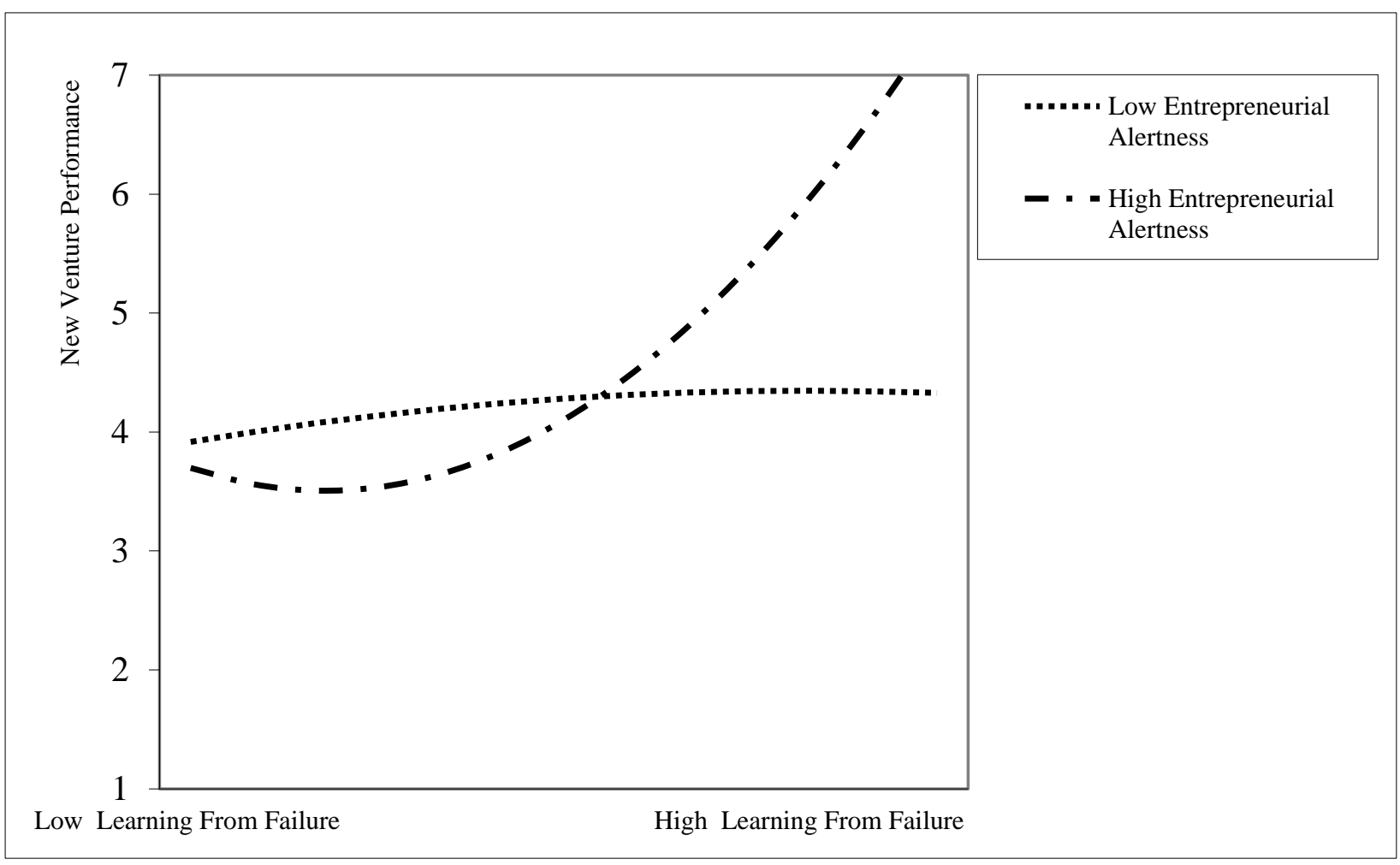




\begin{tabular}{|c|c|}
\hline Details of measures, sources, and results of reliability tests for multi-item constructs & $\begin{array}{c}\text { Standardized } \\
\text { Factor Loadings } \\
\text { (t-values) }\end{array}$ \\
\hline \multicolumn{2}{|l|}{$\begin{array}{l}\text { Learning from failure (Yamakawa and Cardon; 2015; Homsma et al., 2009; Clercq and Sapienza, } \\
\text { 2005): } \alpha=.86 ; \mathrm{CR}=.85 ; \mathrm{AVE}=.60\end{array}$} \\
\hline I am particularly making use of previous failure experience in my current venture. & $.79^{\mathrm{a}}$ \\
\hline I am very sure of making use of previous failure experience in my current venture. & $.70(23.13)$ \\
\hline $\begin{array}{l}\text { The errors I identified from my previous failure experience lead to new insights and/or ideas within } \\
\text { my current venture. }\end{array}$ & $.77(22.29)$ \\
\hline I am applying what I learnt from my previous failure experience in my new business. & $.81(12.86)$ \\
\hline \multicolumn{2}{|l|}{ Alertness scanning and search (Tang, Kacmar and Busenitz, 2012): $\alpha=.88 ; \mathrm{CR}=.87 ; \mathrm{AVE}=.63$} \\
\hline -I have frequent interactions with others to acquire new information. & $.83^{\mathrm{a}}$ \\
\hline -I always keep an eye out for new business ideas when looking for information. & $.84(14.53)$ \\
\hline -I read news, magazines, or trade publications regularly to acquire new information. & $.75(12.63)$ \\
\hline -I am always actively looking for new information. & $.75(12.62)$ \\
\hline \multicolumn{2}{|l|}{$\begin{array}{l}\text { Alertness association and connection (Tang, Kacmar and Busenitz, 2012): } \alpha=.91 ; \mathrm{CR}=.91 ; \mathrm{AVE}= \\
.77\end{array}$} \\
\hline -I see links between seemingly unrelated pieces of information. & $.88^{\mathrm{a}}$ \\
\hline -I am good at "connecting dots". & $.97(20.66)$ \\
\hline -I often see connections between previously unconnected domains of information. & $.77(15.09)$ \\
\hline \multicolumn{2}{|l|}{$\begin{array}{l}\text { Alertness evaluation and judgement (Tang, Kacmar and Busenitz, 2012): } \alpha=.93 ; \mathrm{CR}=.94 ; \mathrm{AVE}= \\
.79\end{array}$} \\
\hline -I have a gut feeling for potential opportunities. & $.88^{\mathrm{a}}$ \\
\hline -I can distinguish between profitable opportunities and not-so-profitable opportunities. & $.90(20.15)$ \\
\hline -I have a knack for telling high-value opportunities apart from low-value opportunities. & $.86(18.56)$ \\
\hline -When facing multiple opportunities, I am able to select the good ones. & $.91(20.68)$ \\
\hline \multicolumn{2}{|l|}{ Social networking (Shane and Cable, 2002$): \alpha=.92 ; \mathrm{CR}=.92 ; \mathrm{AVE}=.78$} \\
\hline $\begin{array}{l}\text {-I can obtain information about my industry from my network of contacts faster than competitors can } \\
\text { obtain the same information. }\end{array}$ & $.87^{\mathrm{a}}$ \\
\hline -I have a professional relationship with someone influential in my industry. & $.91(17.79)$ \\
\hline $\begin{array}{l}\text {-I have engaged with someone influential in my industry in an informal social activity (e.g., playing } \\
\text { tennis). }\end{array}$ & $.87(16.75)$ \\
\hline \multicolumn{2}{|l|}{ Business networking (Lau and Bruton, 2011; Yiu et al., 2007): $\alpha=.94 ; \mathrm{CR}=.93 ; \mathrm{AVE}=.81$} \\
\hline -Customers & $.92^{\mathrm{a}}$ \\
\hline -Suppliers & $.94(23.92)$ \\
\hline -Competitors & $.84(18.89)$ \\
\hline \multicolumn{2}{|l|}{ Local community ties (Acquaah, 2012): $\alpha=.89 ; \mathrm{CR}=.88 ; \mathrm{AVE}=.71$} \\
\hline -Tribal leaders (e.g., local kings, chiefs, representatives) & $.83^{\mathrm{a}}$ \\
\hline -Religious leaders (e.g., pastors, imams, reverend fathers/ sisters) & $.91(16.17)$ \\
\hline -Opinion leaders/ activists & $.79(13.94)$ \\
\hline \multicolumn{2}{|l|}{ Market turbulence (Jaworski and Kohli, 1993): $\alpha=.92 ; \mathrm{CR}=.93 ; \mathrm{AVE}=.81$} \\
\hline -Demand for industry products or services is increasing in my venture's target market. & $0.90^{\mathrm{a}}$ \\
\hline -Products become obsolete quickly in my venture's target markets. & $0.93(22.05)$ \\
\hline -Competition is cut-throat in my target market. & $0.88(19.57)$ \\
\hline \multicolumn{2}{|l|}{ New venture performance (Luk et al., 2008): $\alpha=.94 ; \mathrm{CR}=.95 ; \mathrm{AVE}=.83$} \\
\hline -Unit sales & $.90^{\mathrm{a}}$ \\
\hline -Unit sales growth & $.93(23.13)$ \\
\hline -Market share & $.92(22.29)$ \\
\hline -Market share growth & $.79(16.35)$ \\
\hline
\end{tabular}

$\mathrm{a}=$ fixed to the value of 1.00 
Table 2: Descriptive Statistics and Correlations

\begin{tabular}{|c|c|c|c|c|c|c|c|c|c|c|c|c|c|c|c|c|c|c|}
\hline & Variables & Mean & SD & 1 & 2 & 3 & 4 & 5 & 6 & 7 & 8 & 9 & 10 & 11 & 12 & 13 & 14 & 15 \\
\hline 1. & Venture size & 49 & 14 & & & & & & & & & & & & & & & \\
\hline 2. & Venture age & 14.56 & 11.31 & .47 & & & & & & & & & & & & & & \\
\hline 3. & Number of ventures started $\$$ & 16.45 & 1.76 & .36 & .21 & & & & & & & & & & & & & \\
\hline 4. & Number of partners & 3.00 & 1.75 & .41 & .44 & .27 & & & & & & & & & & & & \\
\hline 5. & Industry & - & - & -.07 & -.06 & -.02 & .01 & & & & & & & & & & & \\
\hline 6. & Gender† & - & - & -.07 & -.05 & -.11 & -.05 & -.01 & & & & & & & & & & \\
\hline 7. & Social networking & 5.28 & 1.02 & -.12 & -.11 & -.17 & -.07 & .08 & .05 & & & & & & & & & \\
\hline 8. & Business networking & 4.95 & 1.02 & -.14 & -.13 & -.19 & -.09 & .15 & .01 & .18 & & & & & & & & \\
\hline 9. & Market turbulence networking & 5.12 & 1.09 & -.15 & -.14 & -.20 & -.09 & .13 & .03 & .39 & .29 & & & & & & & \\
\hline 10. & Local community networking & 5.64 & 1.07 & -.15 & -.12 & -.14 & -.08 & .03 & -.01 & .45 & .37 & .46 & & & & & & \\
\hline 11. & Education $\dagger$ & - & - & -.07 & -.06 & -.02 & .01 & .20 & -.01 & .08 & .15 & .13 & .03 & & & & & \\
\hline 12 . & Entrepreneurial failure experience & 4.68 & 1.86 & .05 & .01 & .02 & -.02 & -.01 & .04 & .39 & .39 & .21 & .42 & -.01 & & & & \\
\hline 13. & Entrepreneurial alertness & 3.74 & 1.07 & .04 & -.03 & -.02 & -.03 & .02 & .03 & -.05 & -.01 & -.03 & -.17 & .02 & .02 & & & \\
\hline 14. & Learning from failure & 5.44 & 1.06 & -.05 & -.09 & -.08 & -.03 & .05 & .01 & .41 & .40 & .46 & .20 & .05 & .42 & .17 & & \\
\hline 15. & New venture performance & 4.27 & 1.41 & .18 & .08 & .15 & .14 & -.05 & .09 & .08 & .05 & .08 & .13 & -.05 & .17 & .07 & .21 & \\
\hline
\end{tabular}

Correlations above .14 are significant at $p<.05 ;+=$ Natural logarithm transformation of the original values; $\mathrm{SD}=\mathrm{Standard}$

Deviation; $\uparrow=$ Dummy variables 
Table 3: Results of the Structural Model Estimation

\begin{tabular}{|c|c|c|c|c|c|c|c|}
\hline \multirow[t]{3}{*}{ Independent Variables } & \multicolumn{7}{|c|}{ Dependent Variables } \\
\hline & \multicolumn{2}{|c|}{ Learning from Failure } & \multicolumn{5}{|c|}{ New Venture Performance } \\
\hline & Model 1 & Model 2 & Model 3 & Model 4 & Model 5 & Model 6 & Model 7\# \\
\hline \multicolumn{8}{|l|}{ Control Paths } \\
\hline Venture size & $.10(1.08)$ & $.09(.92)$ & $.15(1.33)$ & $.15(1.40)$ & $.13(1.21)$ & $.14(1.20)$ & $.12(1.48)$ \\
\hline Venture age & $-.10(-1.06)$ & $-.10(-1.06)$ & $-.14(-1.28)$ & $-.11(-1.02)$ & $-.10(-.98)$ & $-.18(-1.70)$ & $-.17(-1.63)$ \\
\hline Number of ventures Started & $.01(.06)$ & $-.02(-.26)$ & $.03(.30)$ & $.03(.27)$ & $-.02(-.19)$ & $.03(.26)$ & $.07(.65)$ \\
\hline Number of partners & $.03(.34)$ & $.05(.56)$ & $.13(1.76) \dagger$ & $.17(1.78) \dagger$ & $.19(2.07)^{*}$ & $.13(1.38)$ & $.12(1.28)$ \\
\hline Gender & $.02(.30)$ & $.01(.20)$ & $.12(1.82) \dagger$ & $.12(1.96)^{*}$ & $.12(1.86) \dagger$ & $.11(1.79) \dagger$ & $.12(1.95) \dagger$ \\
\hline Social networking & $.13(1.86) \dagger$ & $.07(1.92) \dagger$ & $-.02(-.18)$ & $.04(.43)$ & $-.07(-.85)$ & $-.03(-.39)$ & $-.02(-.23)$ \\
\hline Business networking & $.20(2.85)^{\star \star}$ & $.16(2.28)^{*}$ & $.01(.24)$ & $.04(.44)$ & $-.05(-.60)$ & $-.03(-.37)$ & $-.04(-.48)$ \\
\hline Local community networking & $.38(6.17)^{\star *}$ & $.35(5.66)^{\star *}$ & $.12(1.97)^{*}$ & $.13(1.99)^{*}$ & $.20(2.02)^{\star}$ & $.25(2.63)^{\star *}$ & $.27(2.86)^{\star \star}$ \\
\hline Education & $.01(.04)$ & $.01(.24)$ & $.05(.78)$ & $.01(.30)$ & $.02(.27)$ & $.04(.63)$ & $-.03(-.44)$ \\
\hline Industry & $.02(.99)$ & $.03(1.00)$ & $.01(.94)$ & $.01(.93)$ & $.01(.94)$ & $.01(.96)$ & $.09(.44)$ \\
\hline Market turbulence & $.13(1.66) \dagger$ & $.12(1.65) \dagger$ & $.09(1.23)$ & $.08(1.23)$ & $.07(1.22)$ & $.08(1.22)$ & $.08(1.24)$ \\
\hline \multicolumn{8}{|l|}{ Direct Effect Paths } \\
\hline H1: Failure experience (FE) & & $.15(2.03)$ & & $.22(2.56)^{*}$ & $.10(1.12)$ & $.11(1.24)$ & $.09(1.02)$ \\
\hline H2: Learning from Failure (LF) & & & & & $.20(2.68)^{\star *}$ & $.25(2.99)^{* *}$ & $.18(2.18)^{*}$ \\
\hline Entrepreneurial alertness (EA) & & & & & $-.09(-1.46)$ & $-.06(-.94)$ & $-.19(-1.62)$ \\
\hline Moderating Effect Paths & & & & & & & \\
\hline H3: LF x EA & & & & & & $.07(1.13)$ & $.06(.97)$ \\
\hline LF squared & & & & & & & $.11(1.57)$ \\
\hline LF squared $x$ EA & & & & & & & $.27(2.60)^{\star *}$ \\
\hline \multicolumn{8}{|l|}{ Goodness of Fit Statistics: } \\
\hline $\mathrm{R}^{2}$ & .33 & .34 & .17 & .19 & .20 & .20 & .22 \\
\hline$\Delta \mathrm{R}^{2}$ & - & $.01 *$ & - & $.02 * *$ & $.01 *$ & .00 & $.02 * *$ \\
\hline$\chi^{2} / \mathrm{D} . \mathrm{F}$ & $114.69 / 59$ & $110.03 / 58$ & $123.55 / 63$ & $118.98 / 62$ & $112.10 / 60$ & $112.04 / 59$ & $104.47 / 57$ \\
\hline$\Delta \chi^{2} / \Delta$ D.F. & - & $4.66 / 1 *$ & - & $4.57 / 1 *$ & $6.88 / 1 *$ & 0.06 & $8.57 / 2 *$ \\
\hline RMSEA & .06 & .06 & .06 & .06 & .06 & .06 & .05 \\
\hline SRMR & .03 & .03 & .04 & .03 & .03 & .03 & .03 \\
\hline NNFI & .96 & .97 & .96 & .96 & .96 & .95 & .97 \\
\hline CFI & .98 & .99 & .98 & .99 & .99 & .99 & .99 \\
\hline
\end{tabular}

Critical values of the $t$ distribution for $\alpha=.10, \alpha=.05$, and $\alpha=.01$ (two- tailed test) are $\dagger=1.65, *=1.96$, and $* *=2.58$, respectively

(T-values are reported in parentheses); \# = Results of additional analysis of the moderating effect path. 